\title{
Projected Food-grain Production and Yield in India: An Evidence from State- wise Panel Data Investigation during 1977-2014
}

\author{
Ajay Kumar Singh ${ }^{1^{*}}$ and Bhim Jyoti
}

Date Received: $26^{\text {th }}$ May 2020 / Date Accepted: $9^{\text {th }}$ October 2020

\begin{abstract}
Purpose : This study examines the impact of climatic change on food-grain production and yield using statewise panel data during 1977-2014 in fifteen Indian states. Accordingly, it estimates the projected food-grain production and yield by the years of 2040, 2040, 2060, 2080 and 2100. Finally, it provides the effective practical and effective policy suggestions to reduce the climate change impact on food-grain farming based on existing studies.
\end{abstract}

Research Method: Regression coefficients of food-grain production and yield with climatic and non-climatic factors are estimated using Cobb-Douglas production function model. Marginal impact analysis method is used to examine the projected food-grain production and yield.

Findings : Empirical results infer that most climatic factors have a negative impact on food-grain production and yield in different weather seasons. Projected results are suggested that food-grain production is expected to be declined by 5.25\%, 6.64\%, 8.03\% and 9.57\% by 2040, 2060, 2080 and 2100 respectively. Food-grain yield is likely to be decreased by $1.05 \%, 1.96 \%, 2.87 \%$ and $5.07 \%$ by the aforesaid years.

Research Limitations : This study could not capture impact of inter-states disparities in socio-economic condition of farmers, geographical conditions, agriculture policies and public spending on agriculture and rural development on food-grain production and yield. It also could not include factors such as solar radiation, sun intensity, wind speed and heat wave in empirical investigation.

Originality/Value : It compiles state-wise panel of food-grain production and yield as dependent variables, and climatic variables and non-climatic factors as explanatory variables during 1977-2014. It examines the projected food-grain production and yield.

Keywords: Climatic and non-climatic factors; Cobb-Douglas production function model; Food Security; Food-grain production and yield; India; Marginal impact analysis technique

\section{INTRODUCTION}

Climate change is not a new phenomenon in the world and it has been changing since ancient era. Climatic factors have a significant contribution to maintain the agricultural production activities (Quiggin and Horowitz, 2003; Eid et al., 2006; Cabas et al., 2009; Imran et al., 2019; Jyoti and Singh, 2020). It is evident that climate is a significant driver for production and yields of crops in a geographical region (Adams et al., 1998; Smit and Skinner, 2002; Chen et al., 2004; Falco et al., 2011; Amin et al., 2015; Herath and Thirumarpan, 2017; Panda et al., 2019). Agriculture is one sector which directly depend upon climate change (Toby et al., 1992; Zhai et al., 2009; Basak et al., 2010). Crop choice

\footnotetext{
School of Liberal Arts \& Management, DIT University, Dehradun, Uttarakhand (India).

a.k.seeku@gmail.com

2 Department of Seed Science and Technology, V.C.S.G., UUHF, College of Forestry, Ranichauri, Tehri Garhwal, Uttarakhand (India).
}

(D) http://orcid.org/0000-0003-0429-0925 
and selection of a specific crop for cultivation depend upon the climatic condition. Climate change, therefore, provides the incentive for farmers to select a particular crop for cultivation. Furthermore, different climatic conditions have a vital contribution to increase the crop growth in various phases during sowing to harvesting time of it. For example, wheat crop requires moderate temperature and precipitation during sowing time and it needs moderate maximum temperature and normal rainfall during growth of flowering of this crop. While, wheat crop requires high maximum and minimum temperature without rainfall during harvesting time of it (Panda et al., 2019). Other crops such as rice, sorghum, maize, and others require different climatic conditions in various phases of crop growth to get a better yield. Change in rainfall pattern, increase in maximum and minimum temperature, relative humidity, solar radiation, and other weather factors have a significant impact on production and yield (Amin et al., 2015). Also, high fluctuation in temperature and precipitation have a negative impact on hydrological processes, water resources, water demand, livestock production and agricultural production (Adams et al., 1998; Abeysingha et al., 2016).

Large segments of society are engaged in agriculture sector for their livelihood in larger agrarian economies. Thus, employment and income of the farmers decrease due to decline in agricultural production (Akintunde et al., 2013; Kumar et al., 2016). Climate change, therefore, has a negative impact on livelihood security of the farming community (Jyoti and Singh, 2020). Food prices are expected to increase as decline in food-grain production due to climate change. Economic capacity of people to acquire foodgrain product will decline as food prices increase. Consequently, food security of people will be in risk due to climate change. Furthermore, there are several crops like sugarcane, cotton, sesame, and other oilseed crops provide the raw material to the agro-industries. Hence, production scale of agri-based industries will decline due to low production of cash crops. Accordingly, jobs for industrial workers and government revenue also decrease due to decline in industrial production. However, the impact of climate change on agriculture production will be varied across economies due to diversity in geographical location (Zhai et al., 2009; Amin et al., 2015). As developed economies are located at a higher latitude than developing economies (Zhai et al., 2009), climate change impact on crop production will be positive in developed countries (Mendelsohn et al., 2006).

In India, agriculture sector plays a significant role to meet the food demand of people, and provides employment to agricultural and industrial labours at greater scale (Birthal et al., 2014). It provides raw material to sugar, cotton and oil processing industries. Arable land is decreasing due to industrialization, urbanization and population growth and use of arable land for commercial activities. In addition, the food security, farmer's livelihood security and income, human health, employment opportunities, rural development, trade and agri-based industries are likely to be in an alarming position due to climate change in near future (Kumar et al., 2016; Kumar et al., 2017; Singh et al., 2017; Jyoti and Singh, 2020). In India, several studies have assessed the impact of climatic change on the agricultural production system in various aspects. $1^{\text {st }}$ groups of researchers have examined the impact of climate change on agriculture productivity (monetary value) (Kumar et al., 2016). $2^{\text {nd }}$ group of researchers have estimated the impact of climatic and nonclimatic factors on agriculture productivity (monetary value) of Rabi and Kharif crops (Kumar et al., 2014; Birthal et al., 2014; Kumar et al., 2015; Yadav et al., 2015). $3^{\text {rd }}$ groups of research have assessed the climate change impact of yield and production of individual crop (Attri and Rathore, 2003; Jha and Tripathi, 2011; Panda et al., 2012; Singh et al., 2016; Guntukula, 2019; Jyoti and Singh, 2020). $4^{\text {th }}$ group of studies have examined the expected yield of individual cash and food-grain crop in different climate change sceneries (Auffhammer et al., 2011; Mondal et al., 2014; Mondal et al., 2015; Singh et al., 2017; Singh and Sharma, 2018; Singh and Jyoti, 2019). $5^{\text {th }}$ group of the studies have evaluated the climate change impact on agriculture GDP (Alam, 2013). $6^{\text {th }}$ group of studies have focused on climate change impact on food security and sustainable livelihood security (Kumar et al., 
2017; Singh and Issac, 2018). $7^{\text {th }}$ group of studies have examined the impact of climatic factors on human health (Singh and Singh, 2020).

The empirical results of above-mentioned studies have concluded that the production and yield (quantity) of food-grain and cash crops, agricultural productivity (monetary term), agriculture GDP and human health are expected to be affected due to climate change in India. It is also expected that impact of climate change on agriculture sector would be higher in India (Imran et al., 2019). Hence, numerous studies have claimed that climate change has brought several negative returns for agricultural sector, socio-economic activities and livelihood security of farming community in India. Further, in India, a large number of studies have assessed the impact of climatic and non-climatic factors on productivity, production and area of food-grain and cash crops using different methods. However, limited studies could estimate the climate change on food-grain production and yield in different climate change scenarios in India. Also, earlier studies could not estimate the prediction of foodgrain production and yield in different climate change scenarios in India. Therefore, there is an urgency to get more understanding on climate change impact on food-grain production and yield in India. Due to above-mentioned research gap, the present study is proposed to address the following research questions:

- What may be the expected food-grain production and yield in different climate change scenarios in India?

- What types of climate policy actions may be effective to mitigate the adverse effect of climate change on food-grain farming in India?

The present study achieved following objectives:

- To assess the climate change impact on foodgrain production and yield in selected 15 Indian states using Cobb-Douglas production function approach.

- To estimate the projected food-grain production and yield in different climate change scenarios i.e. 2040, 2040, 2060, 2080 and 2100 in India.
- To provide the effective practical policy suggestions to mitigate the climate change impact on food-grain farming based on existing studies.

\section{MATERIALS AND METHODS}

\section{Description of Study Area and Data Sources}

This study includes state-wise panel data of foodgain production and yield, cropped area under food-grain crops, gross sown area, irrigated area, fertilizer consumption, maximum and minimum temperature, rainfall and precipitation during 1977-2014. Following 15 Indian states are considered in this study: Andhra Pradesh, Assam, Bihar, Gujarat, Haryana, Karnataka, Kerala, Madhya Pradesh, Maharashtra, Odisha, Punjab, Rajasthan, Tamil Nadu, Uttar Pradesh, and West Bengal. Most data are derived from Centre Monitoring Indian Economy (CMIE). Number of rural literate population is collected from different publications of Census (GoI). Daily-wise data on maximum temperature and temperature, rainfall and precipitation are taken from the Indian Meteorological Department (GoI); Indian Institute of Tropical Meteorology and Geographic Information System Online Software. These data were available at district level, therefore, mean values of climatic factors for all districts in a state are used as state-level. Interpolation and extrapolation techniques are used to complete the time series for those variables (e.g. rural literate population) that do not have values (Kumar and Sharma, 2014; Kumar et al., 2016; Kumar et al., 2017; Singh and Sharma, 2018; Singh and Jyoti, 2019).

\section{Explanation of Dependent and Intendent Variables}

Food-grain production (gross production of cereal and pulses crops) and food-grain yield (i.e. food-grain production that is divided by cropped area under cereal and pulses crops) are used as dependent variables. Similar factors as dependent variables are used by Kumar and Sharma (2014); Kumar et al. (2017); Singh and Sharma (2018); Jyoti and Singh (2020). 
Cropped area under food-grain crops, ratio of gross irrigated area with gross sown area, ratio of rural literate population with gross sown area and fertilizer consumption per hectare land are used as an explanatory variable (Kumar and Sharma, 2014; Birthal et al., 2014; Kumar et al., 2016; Singh et al., 2017; Olanrewaju et al., 2017; Singh and Sharma, 2018). Mean values of maximum and minimum temperature, rainfall and precipitation during summer season (March to June), rainy season (June to October) and winter season (November to February) are used as a climatic factor. Coefficient variation in dailywise climatic factors are also used to measure their impact on food-grain production and yield (Cabas et al., 2009; Kumar et al., 2015; Singh et al., 2019). Coefficient variation in climatic factor is estimated as:

$C V=(\sigma / \mu) \times 100$

Here, $\mathrm{CV}$ is coefficient variation, $\sigma$ is standard deviation and $\mu$ is mean value of a specific climatic factor in 365 days in equation (1).

\section{Formulation of Empirical Models}

Scientific research community have used various methods such as production function model, Ricardian cross-sectional model, Crop simulation model, Future agricultural resources model, Agro-ecological zone model or Agroeconomic zone model, and Computable general equilibrium model to estimate the climate change impact on crop yield, agricultural productivity, agricultural GDP and other sectors using primary and secondary data in different countries (Mendelsohn et al., 1994; Darwin, 1999; Quiggin and Horowitz, 2003; Eid et al., 2006; Zhai et al., 2009; Kumar and Sharma, 2014; Singh et al., 2017). Cobb-Douglas production function approach produce the better regression coefficient of explanatory variables in magnitude in agriculture production analysis (Chen et al., 2004; Kumar et al., 2014; Kumar et al., 2016; Kumar et al., 2017; Singh et al., 2017; Jyoti and Singh, 2020). Also, clarification of regression coefficients of explanatory variable is very easy in this approach. This approach, therefore, is used to assess the impact of climatic and non-climatic factors on food-grain production and yield in India. This method assumes that climatic and non-climatic factors are the inputs of food-grain production and yield. The relationship of foodgrain production with climatic and non-climatic factors is used as:

$\log (t f p)_{s t}=\alpha_{0}+\alpha_{1} \log (f g c a)_{s t}+\alpha_{2} \log (\text { riagsa })_{s t}+\alpha_{3}$ $\log (\text { lprigsa })_{s t}+\alpha_{4} \log \left(f_{c p h}\right)_{s t}+\alpha_{5} \log (\text { amaxtss })_{s t}$ $+\alpha_{6} \log (\text { amaxtrs })_{s t}+\alpha_{7} \log (\text { amaxtws })_{s t}+\alpha_{8} \log$

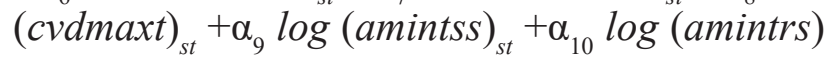
${ }_{s t}+\alpha_{11} \log (\text { amintws })_{s t}+\alpha_{12} \log (c v d \text { mint })_{s t}+\alpha_{13} \log$ (apcpss) $)_{s t}+\alpha_{14} \log$ (apcprs) $)_{s t}+\alpha_{15} \log$ (apcpws) ${ }_{s t}+\alpha_{16} \log (\text { cvdpcp })_{s t}+\alpha_{17} \log (\operatorname{arfss})_{s t}+\alpha_{18} \log$ $(\operatorname{arfrs})_{s t}+\alpha_{19} \log (\operatorname{arfws})_{s t}+\alpha_{20} \log (c v d r f)_{s t}+\eta_{s t}$

Here, tfp is food-grain production; $f g c a$ is cropped area under food-grain crops; riagsa is ratio of gross irrigated area with gross sown area; lprigsa is ratio of rural literate population with gross sown area; $f c p h$ is fertilizer consumption per hectare; amaxtss, amaxtrs and amaxtws are the average maximum temperature summer, rainy and winter seasons respectively; cvdmaxt is coefficient variation in daily-wise maximum temperature, amintss, amintrs and amintws are average minimum temperature in summer, rainy and winter seasons respectively, cvdmint: Coefficient variation in daily-wise minimum temperature; apcpss, apcprs and apcpws are average precipitation in summer, rainy and winter seasons respectively; $c v d p c p$ is coefficient variation in daily-wise precipitation, arfss, arfrs and arfws are average rainfall in summer, rainy and winter seasons respectively; $c v d r f$ is coefficient variation in daily-wise rainfall, $\alpha_{0}$ is constant coefficient; $\log$ is the natural logarithm of corresponding variables; $\alpha_{1} \ldots \alpha_{20}$ are the regression coefficients of associated explanatory variables; $\eta_{s t}$ is the error term; $s$ is cross-sectional state and $t$ is time period in equation (2). The description of dependent and independent variables is presented in Table 01 . 
Table 01: Summary of dependent and independent variables

\begin{tabular}{ccc}
\hline Symbol & Variables & Units \\
\hline$f g p$ & Food-grain production & 000 tonne \\
$f g y$ & Food-grain yield & $\mathrm{Kg}$./Ha. \\
fgca & Cropped area under food-grain crops & $000 \mathrm{Ha}$. \\
riagsa & Ratio of gross irrigated area with gross sown area & Number \\
lprigsa & Ratio of rural literate population with gross sown area & Number \\
fcph & Fertilizer consumption per hectare & $\mathrm{Kg} . / \mathrm{Ha}$. \\
amaxtss & Average maximum temperature in summer season & ${ }^{0} \mathrm{C}$ \\
amaxtrs & Average maximum temperature in rainy season & ${ }^{0} \mathrm{C}$ \\
amaxtws & Average maximum temperature in winter season & ${ }^{0} \mathrm{C}$ \\
cvdmaxt & Coefficient variation in daily-wise maximum temperature & $\%$ \\
amintss & Average minimum temperature in summer season & ${ }^{\circ} \mathrm{C}$ \\
amintrs & Average minimum temperature in rainy season & ${ }^{0} \mathrm{C}$ \\
amintws & Average minimum temperature in winter season & ${ }^{\circ} \mathrm{C}$ \\
cvdmint & Coefficient variation in daily-wise minimum temperature & $\%$ \\
apcpss & Average precipitation in summer season & $\mathrm{mm}$ \\
apcprs & Average precipitation in rainy season & $\mathrm{mm}$ \\
apcpws & Average precipitation in winter season & $\mathrm{mm}$ \\
cvdpcp & Coefficient variation in daily-wise precipitation & $\%$ \\
arfss & Average rainfall in summer season & $\mathrm{mm}$ \\
arfrs & Average rainfall in rainy season & $\mathrm{mm}$ \\
arfws & Average rainfall in winter season & $\mathrm{mm}$ \\
cvdrf & Coefficient variation in daily-wise rainfall & $\%$ \\
\hline
\end{tabular}

Source: Author's compilation

Following empirical model is used to examine the impact of climatic and non-climatic factors on food-grain yield:

$\log (f g y)_{s t}=\beta_{0}+\beta_{1} \log (f g c a)_{s t}+\beta_{2} \log ($ riagsa $)$ ${ }_{s t}+\beta_{3} \log (\operatorname{lprigsa})_{s t}+\beta_{4} \log \left(\right.$ fcph $_{s t}+\beta_{5} \log$ $(\text { amaxtss })_{s t}+\beta_{6} \log (\text { amaxtrs })_{s t}+\beta_{7} \log ($ amaxtws $)$ ${ }_{s t}+\beta_{8} \log (\text { cvdmaxt })_{s t}+\beta_{9} \log (\text { amintss })_{s t}+\beta_{10} \log$ (amintrs) $)_{s t}+\beta_{11} \log (\text { amintws })_{s t}+\beta_{12} \log ($ cvdmint $)$ ${ }_{s t}+\beta_{13} \log (\text { apcpss })_{s t}+\beta_{14} \log$ (apcprs) st $_{s t}+\beta_{15} \log$ $(\text { apcpws })_{s t}+\beta_{16} \log (\text { cvdpcp })_{s t}+\beta_{17} \log (\text { arfss })_{s t}$ $+\beta_{18} \log (\operatorname{arfrs})_{s t}+\beta_{19} \log (\operatorname{arfws})_{s t}+\beta_{20} \log (\mathrm{cvdrf})$ ${ }_{s t}+\delta_{s t}$

Here, $f g y$ is food-grain yield; $\beta_{0}$ is constant coefficient; $\beta_{1} \ldots \beta_{20}$ are the regression coefficients of associated explanatory variables; $\delta_{s t}$ is the error term in equation (3) and description of other variables is presented in equation (2).

\section{Selection of an Appropriate Model}

The present study compiles state-wise panel of 15 states during 1977-2014. These states have a high diversity in food-grain production and yield, and climatic and non-climatic factors. Therefore, following process is followed to select an appropriate form of empirical model. The existence of panel root in each variable is tested trough Im-Pesaran-Shin test (Akintunde et al., 2013; Amin et al., 2015; Jyoti and Singh, 2020). Statistical results based on this test show that all data series are found stationary. The suitability of functional form of proposed model is checked through Ramsay RESET test (Singh and Issac, 2018). Results of this test infer that function form of Cob-Douglas production function model is appeared well-defined. Thereafter, fixed and random effect models are applied to estimate the state and time effect on food-production and yield (Cabas et al., 2009; Jyoti and Singh, 2020). The consistency of random effect model 
is tested through Breusch and Pagan Lagrangian multiplier test. Hausman specification is used to check the suitability of fixed effect model (Cabas et al., 2009; Birthal et al., 2014; Kumar and Sharma, 2014; Kumar et al., 2017). However, this test provides an evidence that either random or fixed effect model can be considered to estimate regression coefficients. Thereupon, Pesaran's test and Breusch-Pagan LM test are applied to identify the presence of crosssectional dependency (Singh and Issac, 2018). Presence of autocorrelation is identified through Wooldridge test (Kumar et al., 2016). Modified Wald test is employed to identify the presence of group-wise heteroskedasticity (Kumar et al., 2016). Statistical results based on Pesaran's test and Modified Wald test provide a confirmation of presence of cross-sectional dependency and heteroskedasticity in panel data. Finally, the regression coefficients of explanatory variables are estimated through feasible generalized least square (FGLS) estimation to reduce the presence of cross-sectional dependency and heteroskedasticity in panel data (Singh and Issac, 2018; Jyoti and Singh, 2020). Proposed regression model is run through STATA statistical software.

\section{Projected Food-grain Production and Yield}

Marginal impact analysis technique is useful to assess the contribution of each factor in production activities (Eid et al., 2006; Kumar et al., 2016; Cabas et al., 2009; Singh et al., 2017; Singh and Sharma, 2018). It measures the expected variation in production due to marginal change in explanatory variables. Hence, regression coefficient of explanatory variables are used to project the food-grain production and yield by 2040, 2060, 2080 and 2100. For this, it assumes that rainfall will be fluctuated by 4, 5, 6 and 7 $\mathrm{mm}$; precipitation will fluctuate by $4,5,6$, and $7 \mathrm{~mm}$; and surface temperature will increase by $0.5,0.75,1.00$ and $1.5^{\circ} \mathrm{C}$ by the aforesaid years (Kumar et al., 2016; Singh et al., 2017; Singh and Sharma, 2018; Jyoti and Singh, 2020). The projected food-grain production is estimated as:

$$
\begin{aligned}
& \Delta(t f p)=\left[\left(\frac{d(t f p)}{d(\text { amaxts })}\right) * \Delta(\text { amaxtss })+\right. \\
& \left(\frac{d(t f p)}{d(\text { amaxtrs })}\right) * \Delta(\text { amaxtrs })+\left(\frac{d(t f p)}{d(\text { amaxtws })}\right) * \\
& \Delta(\text { amaxtws })+\left(\frac{d(t f p)}{d(\text { cvdmaxt })}\right) \Delta(\text { cvdmaxt })+ \\
& \left(\frac{d(t f p)}{d(\text { amintss })}\right) * \Delta(\text { amintss })+\left(\frac{d(t f p)}{d(\text { amintrs })}\right) * \\
& \Delta(\text { amintrs })+\left(\frac{d(t f p)}{d(\text { amintws })}\right) \Delta(\text { amintws })+ \\
& \left(\frac{d(t f p)}{d(\text { cvdmint })}\right) * \Delta(\text { cvdmint })+\left(\frac{d(t f p)}{d(\text { apcpss })}\right) * \\
& \Delta(\text { apcpss })+\left(\frac{d(t f p)}{d(a p c p r s)}\right) \Delta(\text { apcprs })+ \\
& \left(\frac{d(t f p)}{d(\text { apcpws })}\right) * \Delta(\text { apcpws })+\left(\frac{d(t f p)}{d(c v d p c p)}\right) * \\
& \Delta(\text { cvdpcp })+\left(\frac{d(t f p)}{d(\text { arfss })}\right) \Delta(\text { arf } s s)+\left(\frac{d(t f p)}{d(a r f r s)}\right) * \\
& \Delta(\text { arfrs })+\left(\frac{d(t f p)}{d(\text { arfws })}\right) * \Delta(\text { arf } s s)+ \\
& \left.\left(\frac{d(t f p)}{d(\text { cvdrf })}\right) \Delta(\text { cvdrf })\right]
\end{aligned}
$$

Here, $t f p$ is projected food-grain production; $\Delta$ shows the change in associated climatic factors; $d(t f p) / d($ amaxtss $), \quad d(t f p) / d($ amaxtrs $)$, $d(t f p) / d($ amaxtws $), \ldots, d(t f p) / d(c v d r f)$ are the first derivate of food-grain production function with respect to corresponding climatic factors in equation (4). The description of all variables is given in equation (2). Food-grain yield is projected as:

$$
\begin{aligned}
& \Delta(f g y)=\left[\left(\frac{d(\text { fgy })}{d(\text { amaxtss })}\right) * \Delta(\text { amaxtss })+\right. \\
& \left(\frac{d(f g y)}{d(\text { amaxtrs })}\right) * \Delta(\text { amaxtrs })+\left(\frac{d(f g y)}{d(\text { amaxtws })}\right) * \\
& \Delta(\text { amaxtws })+\left(\frac{d(f g y)}{d(\text { cvdmaxt })}\right) \Delta(\text { cvdmaxt })+ \\
& \left(\frac{d(\text { fgy })}{d(\text { amints })}\right) * \Delta(\text { amintss })+\left(\frac{d(\text { fgy })}{d(\text { amintrs })}\right) * \\
& \Delta(\text { amintrs })+\left(\frac{d(f g y)}{d(\text { amintws })}\right) \Delta(\text { amintws })+ \\
& \left(\frac{d(f g y)}{d(c v d \min t)}\right) * \Delta(\text { cvdmint })+\left(\frac{d(f g y)}{d(\text { apcpss })}\right) * \\
& \Delta(\text { apcpss })+\left(\frac{d(f g y)}{d(\text { apcprs })}\right) \Delta(\text { apcprs })+ \\
& \left(\frac{d(f g y)}{d(\text { apcpws })}\right) * \Delta(\text { apcpws })+\left(\frac{d(f g y)}{d(c v d p c p)}\right) * \\
& \Delta(\text { cvdpcp })+\left(\frac{d(f g y)}{d(\text { arfss })}\right) \Delta(\text { arfss })+\left(\frac{d(f g y)}{d(\text { arfrs })}\right) * \\
& \Delta(\operatorname{arfrs})+\left(\frac{d(f g y)}{d(a r f w s)}\right) * \Delta(\operatorname{arfss})+ \\
& \left.\left(\frac{d(f g y)}{d(c v d r f)}\right) \Delta(c v d r f)\right]
\end{aligned}
$$$$
\text { (5) }
$$

5) 
Here $f g y$ is projected food-grain yield production; $\Delta$ shows the change in associated climatic factors; $d(f g y) / d($ amaxtss $), d(f g y) / d$ (amaxtrs), $d(f g y) / d($ amaxtws $), \ldots, d(t f p) / d(c v d r f)$ are the first differentiation of food-grain yield function with respect to corresponding climatic factors in equation (5). The description of all variables is given in equation (2).

\section{DISCUSSION ON DESCRIPTIVE RESULTS}

\section{Correlation Coefficients of Food-grain Production with Non-climatic and Climatic Factors}

Trend in food-grain production, food-grain cropped area, fertilizer consumption, ratio of irrigated area with gross sown area and ratio of rural literate population with gross sown area during 1977-2014 is presented in Figure 01. Karl-Pearson correlation coefficients of foodgrain production with aforementioned factors is presented in Table 02. Results show that food-grain production is positively correlated with aforesaid factors (except ratio of rural literate population with gross sown area). Thus, it is suggested that India needs to focus to increase area under food-grain crops, fertilizer consumption and irrigated area to increase foodgrain production.
Trend in food-grain production, and annual average maximum temperature, minimum temperature, precipitation and rainfall is presented in Figure 02. The correlation coefficient of food-grain production with climatic factors is presented in Table 02. Results demonstrate the food-grain production is negatively associated with climatic factors.

\section{Correlation Coefficients of Food-grain Yield with Non-climatic and Climatic Factors}

Trend in food-grain yield with non-climatic and climatic factors are presented in Figure 03 and Figure 04 respectively. Accordingly, KarlPearson correlation coefficients of food-grain yield with climatic and non-climatic factors is presented in Table 03. Descriptive results infer that food-grain yield is positively associated with ratio of irrigated area with gross sown area, fertilizer consumption per hectare land and ratio of rural literate population with gross sown area. Annual average maximum and minimum temperature, precipitation and rainfall have a negative effect on food-grain yield. Thus, it seemed that food-grain yield is expected to be diminished as increase in climatic factors.

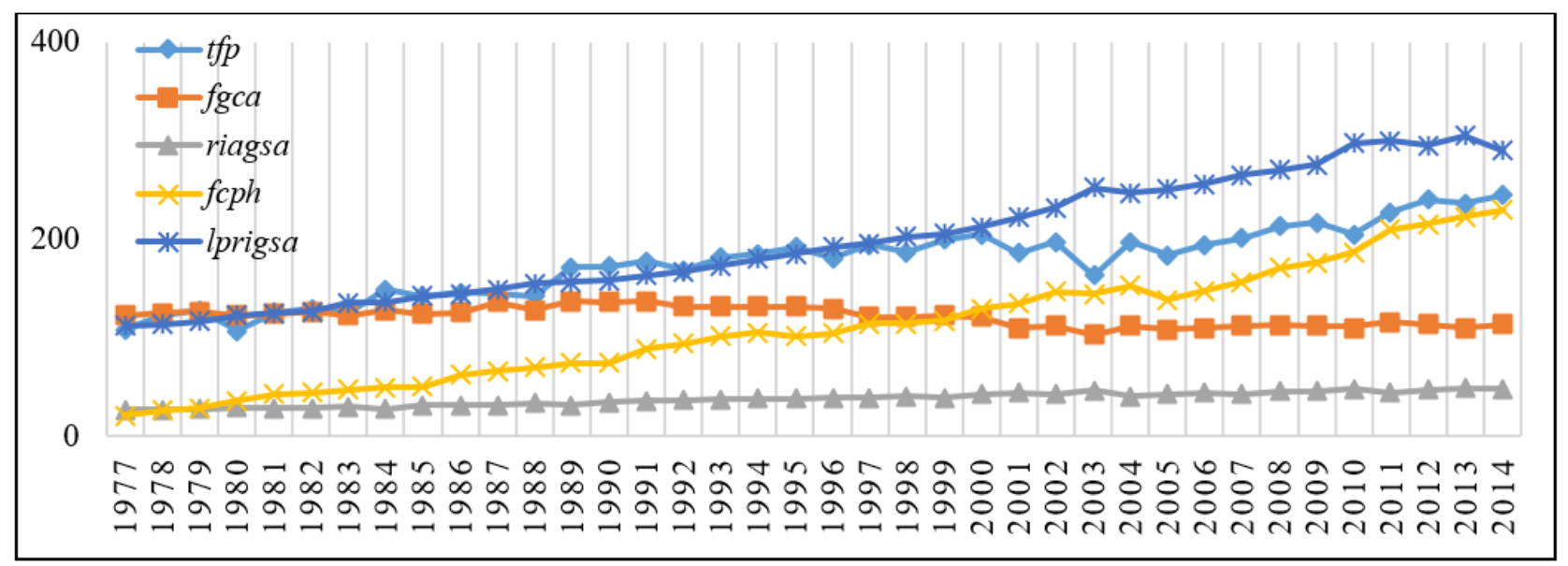

Source: Author's estimation. Note: tfp-total food-grain production ('000000'tonne), fgca-food-grain cropped area ('00000' Ha.), riagsa- \% of irrigated area with gross sown area, fcph-fertilizer consumption (Kg./Ha.), and lprigsa-ratio of rural literate population with gross sown area (Number/'00'Ha.).

Figure 01: Trend in food-grain production and non-climatic factors 


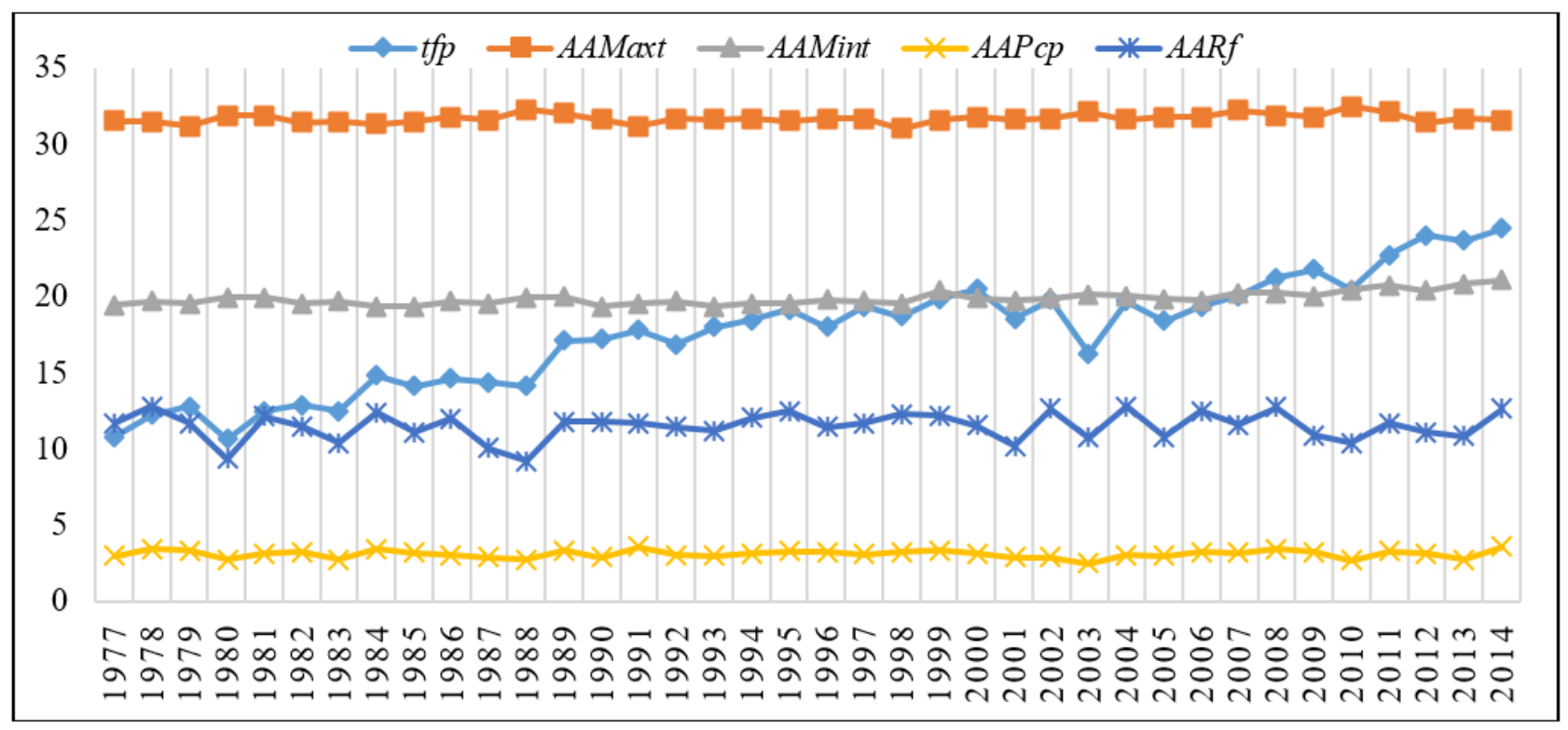

Source: Author's estimation. Note: tfp-total food-grain production (in '0000000'tonne), AAMaxt-Annual average maximum temperature (in ${ }^{\circ} \mathrm{C}$ ), AAMint-Annual Average minimum temperature (in ${ }^{\circ} \mathrm{C}$ ), AAPcp-Annual average precipitation (in mm), and AARf-Annual average rainfall (in '00' $\mathrm{mm}$ ).

Figure 02: Trend in food-grain production and climatic factors

Table 02: Correlation coefficient of food-grain production with explanatory variables

\begin{tabular}{lccccccccc}
\hline \multicolumn{1}{c}{ Factors } & $f g p$ & riagsa & $f g c a$ & $f c p h$ & lprigsa & aamaxt & aamint & aapcp & aarf \\
\hline fgp & 1 & & & & & & & & \\
riagsa & $0.5587^{*}$ & 1 & & & & & & & \\
fgca & $0.6979^{*}$ & 0.0039 & 1 & & & & & & \\
fcph & $0.1496^{*}$ & $0.5466^{*}$ & $-0.1839^{*}$ & 1 & & & & & \\
lprigsa & $-0.1991^{*}$ & -0.0733 & $-0.4514^{*}$ & -0.0176 & 1 & & & & \\
aamaxt & -0.0208 & $-0.2600^{*}$ & $0.3328^{*}$ & $-0.1631^{*}$ & $-0.2641^{*}$ & 1 & & \\
aamint & $-0.3852^{*}$ & $-0.4630^{*}$ & $-0.3125^{*}$ & $-0.2435^{*}$ & $0.4642^{*}$ & $0.4181^{*}$ & 1 & & \\
aapcp & $-0.3329^{*}$ & $-0.4655^{*}$ & $-0.3610^{*}$ & $-0.2700^{*}$ & $0.6093^{*}$ & $-0.3988^{*}$ & $0.3990^{*}$ & 1 & \\
aarf & $-0.3790^{*}$ & $-0.4449^{*}$ & $-0.4080^{*}$ & $-0.2588^{*}$ & $0.6195^{*}$ & $-0.3967^{*}$ & $0.3938^{*}$ & $0.8853^{*}$ & 1 \\
\hline
\end{tabular}

Source: Author's estimation. Note: ** and * show that correlation coefficient is significant at the $1 \%$ and $5 \%$ significance level respectively.

Table 03: Correlation coefficient of food-grain yield with explanatory variables

\begin{tabular}{lccccccccc}
\hline \multicolumn{1}{c}{ Factors } & $f g y$ & riagsa & $f g c a$ & $f c p h$ & lprigsa & aamaxt & aamint & aapcp & aarf \\
\hline fgy & 1 & & & & & & & & \\
riagsa & $0.7751^{*}$ & 1 & & & & & & & \\
fgca & $-0.3013^{*}$ & 0.0039 & 1 & & & & & & \\
fcph & $0.5749^{*}$ & $0.5466^{*}$ & $-0.1839^{*}$ & 1 & & & & & \\
lprigsa & $0.2592^{*}$ & -0.0733 & $-0.4514^{*}$ & -0.0176 & 1 & & & & \\
aamaxt & $-0.4566^{*}$ & $-0.2600^{*}$ & $0.3328^{*}$ & $-0.1631^{*}$ & $-0.2641^{*}$ & 1 & & \\
aamint & $-0.2526^{*}$ & $-0.4630^{*}$ & $-0.3125^{*}$ & $-0.2435^{*}$ & $0.4642^{*}$ & $0.4181^{*}$ & 1 & & \\
aapcp & -0.0584 & $-0.4655^{*}$ & $-0.3610^{*}$ & $-0.2700^{*}$ & $0.6093^{*}$ & $-0.3988^{*}$ & $0.3990^{*}$ & 1 & \\
aarf & -0.0569 & $-0.4449^{*}$ & $-0.4080^{*}$ & $-0.2588^{*}$ & $0.6195^{*}$ & $-0.3967^{*}$ & $0.3938^{*}$ & $0.8853^{*}$ & 1 \\
\hline
\end{tabular}

Source: Author's estimation. Note: ** and * show that correlation coefficient is significant at the $1 \%$ and $5 \%$ significance level respectively. 


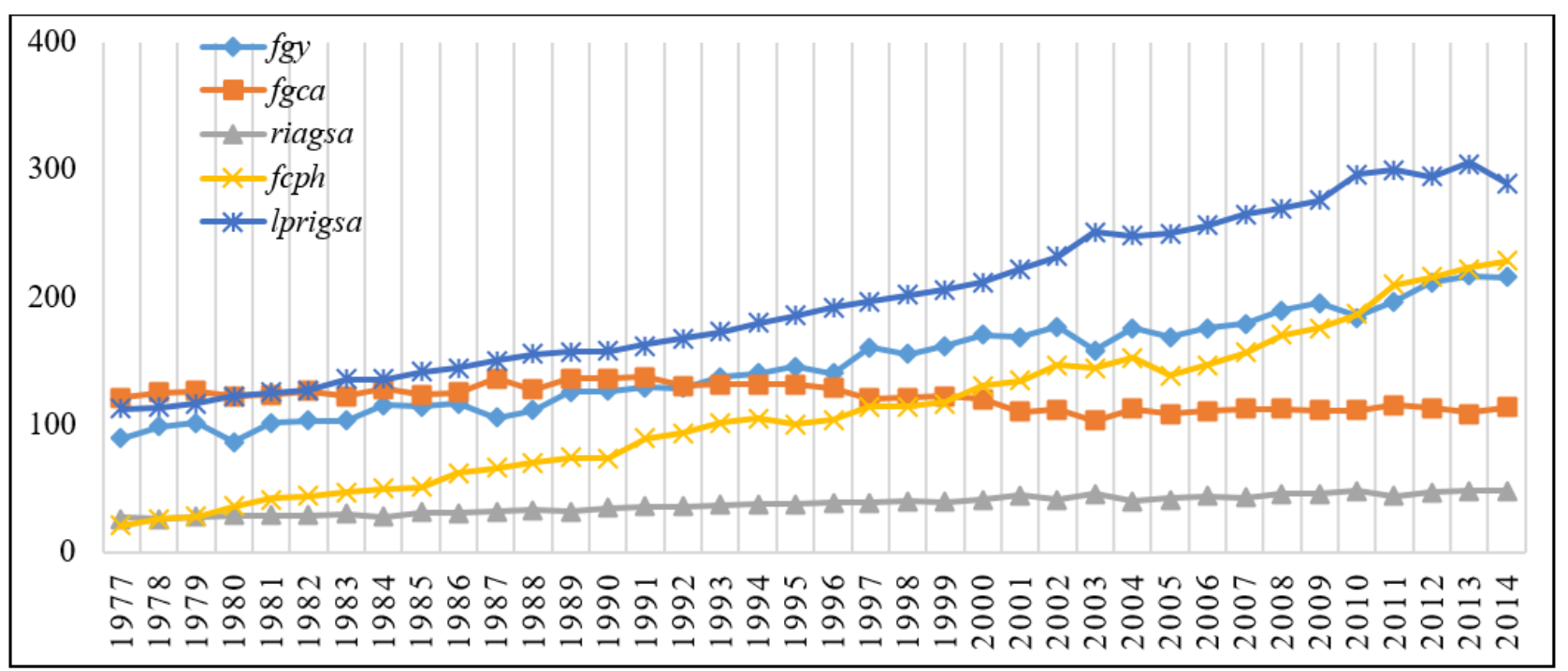

Source: Author's estimation. Note: fgy-Food-grain yield ('0'Kg./Ha.), fgca-food-grain cropped area ('000' Ha.), riagsa- \% of irrigated area with gross sown area, fcph-fertilizer consumption (Kg./Ha.), and lprigsa-ratio of rural literate population with gross sown area (Numbers/'00’Ha.).

Figure 03: Trend in food-grain yield and non-climatic factors

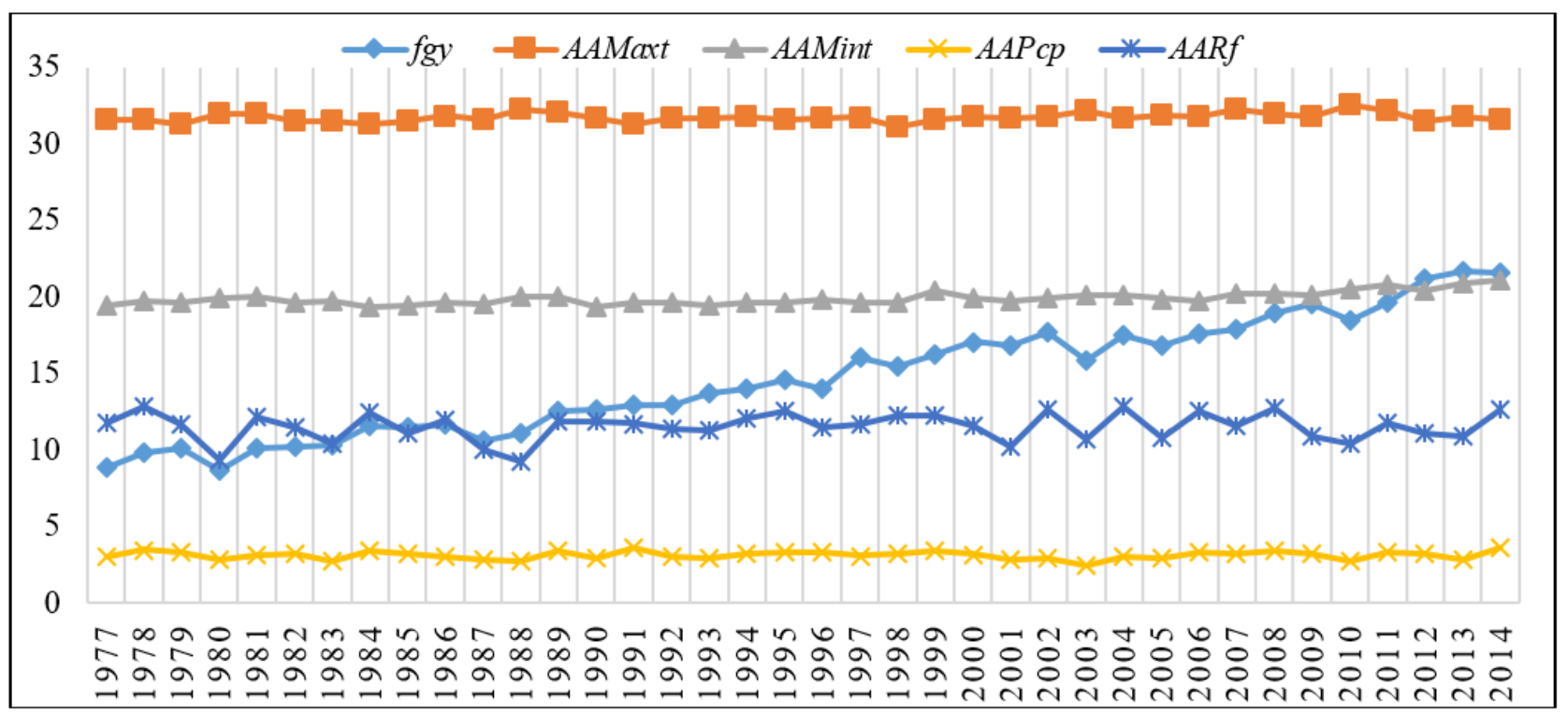

Source: Author's estimation. Note: fgy-Food-grain yield ('0'Kg./Ha.), AAMaxt-Annual average maximum temperature (in ${ }^{\circ} \mathrm{C}$ ), AAMintAnnual Average minimum temperature $\left(\right.$ in ${ }^{\circ} \mathrm{C}$ ), AAPcp-Annual average precipitation (in $\mathrm{mm}$ ), and AARf-Annual average rainfall (in '00' $\mathrm{mm})$.

\section{Figure 04: Trend in food-grain yield and climatic factors}

\section{DISCUSSION ON EMPIRICAL RESULTS}

Regression coefficients of food-grain cropped area, ratio of irrigated area with gross sown area, ratio of literate population with gross sown area and fertilizer consumption with food-grain production are seemed positive and statistically significant (See Table 04). Thus, it is proposed that cropped area under food-grain crops, irrigated area, and contribution of literate population and consumption of fertilizer in cultivation are found crucial inputs to maintain food-grain production. Furthermore, irrigated area has a higher yield capacity as compared to non-irrigated area (Reddy, 2006; Birthal et al., 2014; Kumar et al., 2014; Kumar and Sharma, 2014; Jyoti and Singh, 2020). As literate population has a greater understanding on farm management practices, use of appropriate quantity of fertilizer/hectare land, accurate time for irrigation and sowing time of seed, use of mechanization in farming and better information on climate change (Kumar et al., 
2017; Singh and Issac, 2018). Thus, regression coefficients of ratio of irrigated area with gross sown area, ratio of literate population with gross sown area and fertilizer consumption with foodgrain yield are found positive. Also, irrigated area and contribution of literate population are useful to mitigate the adverse effect of climate change in agriculture. Food-grain cropped area produced a negative impact on food-grain yield. This result is consistent with previous studies such as Cabas et al. (2009) that have argued that output per hectare land is likely to be decreased due to existence of law of diminishing return in farming activities.

Table 04: $\quad$ Regression coefficients of variables with food-grain production and yield

\begin{tabular}{|c|c|c|c|c|c|c|}
\hline Form of Function & \multicolumn{3}{|c|}{ Food-grain production Function } & \multicolumn{3}{|c|}{ Food-grain yield Function } \\
\hline Number of Obs. & \multicolumn{3}{|c|}{560} & \multicolumn{3}{|c|}{560} \\
\hline Wald chi2 (16) & \multicolumn{3}{|c|}{11537.9} & \multicolumn{3}{|c|}{3097.94} \\
\hline Prob $>$ chi 2 & \multicolumn{3}{|c|}{0.000} & \multicolumn{3}{|c|}{0.000} \\
\hline Log likelihood & \multicolumn{3}{|c|}{-146.3737} & \multicolumn{3}{|c|}{-146.271} \\
\hline $\begin{array}{l}\text { Ramsey RESET } \\
\text { test [fitted values] }\end{array}$ & \multicolumn{3}{|c|}{5.06} & \multicolumn{3}{|c|}{8.06} \\
\hline $\begin{array}{l}\text { Ramsey RESET } \\
\text { test [Independent } \\
\text { variables] }\end{array}$ & \multicolumn{3}{|c|}{9.18} & \multicolumn{3}{|c|}{9.18} \\
\hline $\begin{array}{c}\text { Explanatory } \\
\text { Variables }\end{array}$ & Reg. Coef. & Std. Err. & $P>|z|$ & Coef. & Std. Err. & $P>|z|$ \\
\hline fgca & $0.9207 *$ & 0.019 & 0.000 & $-0.0793 *$ & 0.019 & 0.000 \\
\hline riagsa & $0.1860 *$ & 0.020 & 0.000 & $0.1862 *$ & 0.020 & 0.000 \\
\hline lprigsa & $0.0683 * * *$ & 0.027 & 0.011 & $0.0680^{*}$ & 0.027 & 0.011 \\
\hline$f_{c p h}$ & $0.2207^{*}$ & 0.012 & 0.000 & $0.2208^{*}$ & 0.012 & 0.000 \\
\hline amaxtss & $-3.3104 *$ & 0.539 & 0.000 & $-3.3123 *$ & 0.539 & 0.000 \\
\hline amaxtrs & -0.2290 & 0.608 & 0.706 & -0.2320 & 0.608 & 0.703 \\
\hline amaxtws & -0.2171 & 0.514 & 0.673 & -0.2140 & 0.514 & 0.676 \\
\hline cvdmaxt & 0.1899 & 0.136 & 0.164 & 0.1890 & 0.137 & 0.166 \\
\hline amintss & $2.1887^{*}$ & 0.411 & 0.000 & $2.1886^{*}$ & 0.411 & 0.000 \\
\hline amintrs & -0.1315 & 0.591 & 0.824 & -0.1300 & 0.591 & 0.825 \\
\hline amintws & $-0.6905^{*}$ & 0.243 & 0.005 & $-0.6916^{*}$ & 0.243 & 0.004 \\
\hline cvdmint & -0.0955 & 0.129 & 0.458 & -0.0959 & 0.129 & 0.460 \\
\hline apcpss & -0.0161 & 0.022 & 0.456 & -0.0160 & 0.022 & 0.458 \\
\hline apcprs & $0.1487 *$ & 0.039 & 0.000 & $0.1486^{*}$ & 0.039 & 0.000 \\
\hline apcpws & $0.0346 *$ & 0.013 & 0.006 & $0.0347 *$ & 0.013 & 0.006 \\
\hline$c v d p c p$ & -0.0873 & 0.070 & 0.212 & -0.087 & 0.070 & 0.215 \\
\hline $\operatorname{arfss}$ & $-0.0201 * * *$ & 0.012 & 0.099 & $-0.0200 * * *$ & 0.012 & 0.102 \\
\hline $\operatorname{arfrs}$ & -0.0237 & 0.027 & 0.381 & -0.0240 & 0.027 & 0.383 \\
\hline arfws & $0.0259 * *$ & 0.011 & 0.018 & $0.0257^{* *}$ & 0.011 & 0.018 \\
\hline$c v d r f$ & -0.0343 & 0.045 & 0.447 & -0.0350 & 0.045 & 0.433 \\
\hline Con. Coef. & $8.6295^{*}$ & 2.019 & 0.000 & $15.5459 *$ & 2.020 & 0.000 \\
\hline
\end{tabular}

Source: Author's estimation. Note: *,**, and *** indicate the parameter is statistically significant at the $1 \%, 5 \%$ and $10 \%$ significance level respectively. 
Result also proposes that farming community must use a minimum quantity of fertilizer in agriculture. Earlier studies have claimed that use of fertilizer have a positive impact on production and yield in short-run (Kumar et al., 2016). However, use of fertilizer has a negative impact on soil quality and environmental factors in longrun (Kumar et al., 2014). GHGs emissions also increase due to the use of extensive fertilizer in cultivation, thus it would cause to increase more possibilities of climate change (Kumar et al., 2015). Extensive use of fertilizer in cultivation may cause to reduce actual nutritional content in food-grain, thus it would have a negative impact on human health. It is recommended to improve the scientific methods on the use of fertilizer in cultivation to increase the crop yield (Reddy, 2006).

Maximum temperature during summer, rainy and winter seasons show a negative impact on foodgrain production and yield. Estimate is consistent with previous studies such as Kumar et al. (2014); Singh et al. (2016); Singh and Narayanan (2018); Singh and Sharma (2018) have also noticed a negative effect of maximum and minimum temperature on production and yield of various food-grain crops in India. Regression coefficient of minimum temperature during summer season has a positive impact on food-grain production and yield. Food-grain production and yield are likely to decrease as the minimum temperature increases during rainy and winter seasons. Regression coefficient of precipitation during summer season is seemed negative, thus it shows that food-grain production and yield are expected to be declined as precipitation increases during summer seasons. In contrary, precipitation during rainy and winter seasons show a positive influence on food-grain production and yield. Impact of rainfall during summer and rainy seasons on food-grain production and yield are found negative. As rainfall pattern during summer and rainy seasons are changing and highly fluctuated, thus rainfall shows a negative influence on food-grain production and yield. Rainfall during winter season has a positive impact on food-grain production and yield. Coefficient variation in minimum temperature, precipitation and rainfall also have a negative impact on food-grain production and yield. Thus, food-grain production and yield have a tendency to be declined as increase in daily variation in minimum temperature, precipitation and rainfall.

\section{Validity Test for Regression Coefficients}

Regression coefficients of explanatory variables with output may be used to estimate the future prediction (Singh et al., 2017). If correlation coefficients of error terms with its first two lags are statistically significant, thereafter, the regression coefficients can be considered valid. Therefore, auto-correlation coefficients and partial auto-correlation coefficients among the different lags of residual terms are presented in Table 5. Accordingly, correlation coefficients of residual terms with its respective lags are seemed positive and statistically significant for foodgrain production and yield function. Thus, it is clear that regression coefficients are valid and these can be used for estimation of projected food-grain production and yield.

\section{Projected Food-grain Production and Yield}

Food-grain production and yield are projected using marginal impact analysis techniques (See Figure 05). These are based on regression coefficients of climatic factors with food-grain production and yield during 1977-2014. It infers that food-grain production is expected to be declined by $5.25 \%, 6.64 \%, 8.03 \%$ and $9.57 \%$ by the years of 2040, 2060, 2080 and 2100 respectively. Food-grain yield is likely to be decreased by $1.05 \%, 1.96 \%, 2.87 \%$ and $5.07 \%$ by the years of 2040, 2060, 2080 and 2100. Birthal et al. (2014) have reported that the yields of rice, maize, sorghum, pigeonpea, groundnut, wheat, barley, chickpea and mustard are expected to be declined due to climate change in India. Kumar et al. (2014) has also found that yields of rice, maize, sorghum and ragi crops will be declined due to climate change. Singh and Sharma (2018) have also reported that yields of rice, Arahr, Bajara and Jowar crops are likely to be declined by the years of 2040, 2060, 2080 and 2100 . 
Table 05: Correlation coefficients between error term and its various lags for food-grain production and yield function

\begin{tabular}{ccccc}
\hline \multirow{2}{*}{$\begin{array}{c}\text { No. of } \\
\text { Lags }\end{array}$} & \multicolumn{2}{c}{ Auto-correlation coefficients } & \multicolumn{2}{c}{ Partial auto-correlations } \\
\cline { 2 - 5 } & $\begin{array}{c}\text { Food-grain } \\
\text { production function }\end{array}$ & $\begin{array}{c}\text { Food-grain yield } \\
\text { function }\end{array}$ & $\begin{array}{c}\text { Food-grain } \\
\text { production function }\end{array}$ & $\begin{array}{c}\text { Food-grain yield } \\
\text { function }\end{array}$ \\
\hline 1 & $0.7253^{*}$ & $0.7641^{*}$ & $0.3322^{*}$ & $0.2832^{*}$ \\
2 & $0.6369^{*}$ & $0.7277^{*}$ & 0.0709 & $0.1315^{*}$ \\
3 & $0.5811^{*}$ & $0.6922^{*}$ & 0.0391 & $0.1123^{* *}$ \\
4 & $0.5919^{*}$ & $0.6487^{*}$ & 0.0292 & -0.0761 \\
5 & $0.6310^{*}$ & $0.6809^{*}$ & $0.1329^{*}$ & $0.1670^{*}$ \\
6 & $0.6469^{*}$ & $0.6547^{*}$ & $0.1329^{*}$ & 0.0347 \\
7 & $0.6611^{*}$ & $0.6604^{*}$ & $0.1697^{*}$ & $0.1280^{* * *}$ \\
8 & $0.5781^{*}$ & $0.6410^{*}$ & $-0.0840^{* *}$ & 0.0767 \\
9 & $0.5472^{*}$ & $0.5733^{*}$ & 0.0224 & -0.0623 \\
\hline
\end{tabular}

Source: Author's estimation. Note: *, **, and *** indicate the parameter is statistically significant at the $1 \%, 5 \%$ and $10 \%$ significance level respectively.

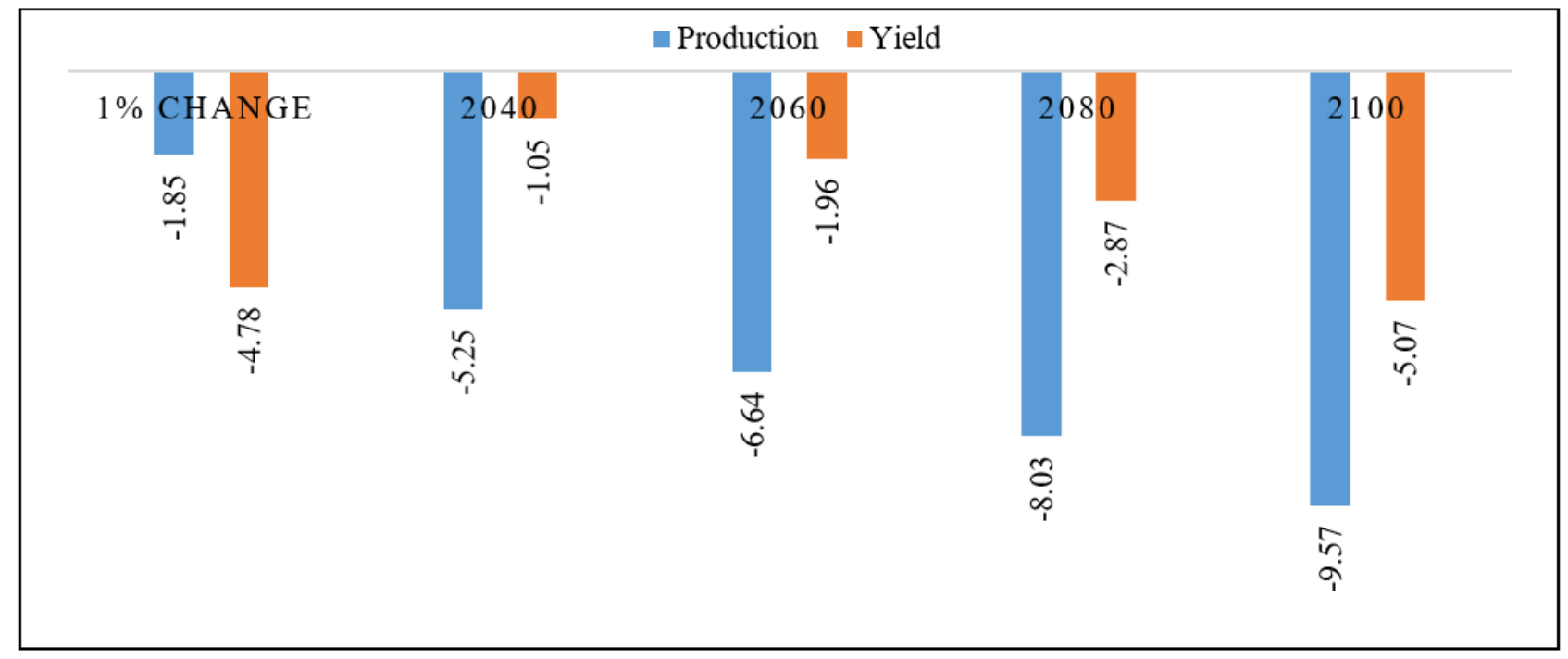

Source: Author's Estimation.

Figure 05: $\quad$ Expected food-grain production and yield in 2040, 2060, 2080 and 2100

CONCLUSIONAND POLICY GUIDELINES

The present study assesses the influence of climatic and non-climatic factors on foodgrain production and yield in 15 Indian states using Cobb-Douglas production function model. It compiles a state-wise panel of foodgrain production and yield as dependent variables, and climatic and non-climatic factors as independent variables during 1977-2014. Thereupon, it examines the projected foodgrain production and yield in different climate change scenarios (i.e. 2040, 2060, 2080 and 2100) using marginal impact analysis technique. Finally, it provides viable policy suggestions to reduce the adverse effect of climate change in agriculture production system based on existing studies. Descriptive results show that foodgrain production is positively associated with irrigated area, cropped area and fertilizer. Foodgrain yield is positively associated with irrigated area, fertilizer consumption and involvement of literate population in cultivation. Maximum and minimum temperature, precipitation and rainfall show a negative impact on food-grain production and yield.

Regression results indicate that food-grain production and yield improve as increases in irrigated area, participation of literate population 
in farming and fertilizer consumption. These factors, therefore, may be useful to reduce the negative implications of climate change in the agriculture production system. Impact of maximum temperature during summer, rainy and winter seasons on food-grain production and yield are seemed negative. Regression coefficients of minimum temperature during rainy and winter season with food-grain production and yield are also found negative. Thus, estimates infer that food-grain production and yield are expected to be declined as increase in maximum and minimum temperature. Food-grain production and yield are being negatively impacted due to high fluctuation in rainfall during summer and rainy seasons. It exists due to change in rainfall pattern and high fluctuation in rainfall during rainy season. However, regression coefficient of precipitation with food-grain production and yield during rainy and winter seasons are appeared positive. Thus, precipitation will be helpful to increase food-grain production and yield. Therefore, most climatic factors during summer, rainy and winter seasons show a negative impact on food-grain production and yield. The results, therefore, show that production and yield of food-grain crops are highly sensitive due to fluctuation in climatic factors in various seasons.

Projected results show that food-grain production is expected to be declined by $5.25 \%, 6.64 \%$, $8.03 \%$ and $9.57 \%$ by the years of $2040,2060,2080$ and 2100 respectively. Food-grain yield is also likely to be decreased by $1.05 \%, 1.96 \%, 2.87 \%$ and $5.07 \%$ by the aforesaid years. As results it clearly indicates that food-grain production and yield are expected to be declined due to climate change in India. Food security and livelihood security of people, therefore, will be in a worse position in India. Hence, for India, it is essential to adopt a sustainable agricultural management policy to mitigate the adverse implications of climate change on food-grain farming to ensure the food security of India at a greater level.

Several policy suggestions can be given to increase the food-grain production and yield and to mitigate the adverse effect of climate change on it. As agricultural land and irrigation facilities are vital inputs, there must be a conducive policy to maintain reserve arable land to increase food-grain production in India. Furthermore, India needs to control high urbanization, industrialization and population growth to sustain arable land and food-grain production in India. There also exists a requirement to increase irrigation facilities to increase food-grain yield and production (Kumar et al., 2014; Kumar et al., 2015; Singh et al., 2016; Kumar et al., 2017). For this, water conservation management policies will be effective to meet the irrigation requirement in agriculture, and therefore, it is essential to use micro-irrigation techniques such as sprinkler and drip irrigation in agriculture (Birthal et al., 2014). Water management practises will also be useful to increase the crop yield (Reddy, 2006). Water storage must be considered through a water sustainable management system to meet the irrigation requirement for the agriculture production system (Herath and Thirumarpan, 2017; Singh et al., 2017). There requires to adopt policies to increase agriculture sustainability by using green fertilizer in cultivation that abate the GHGs emissions (Singh and Jyoti, 2019).

Crop insurance policies and appropriate credit facilities for the farmers will be useful to increase their economic capacity (Birthal et al., 2014; Kumar et al., 2017), thereby farmers will be in a position to recover their monetary loss of agricultural production due to climate change. Infrastructure development (i.e. road connective from rural to urban area and well market structure) will be useful to increase the farmer's connectivity to market and urban areas. Thus, it will be helpful to sustain agricultural production activities. More establishment of agriculture extension offices may be supportive to provide the appropriate information on climate change to the farmers (Singh et al., 2016). Application of advance technologies in cultivation and public spending on agriculture research and development may be effective to increase crop yield and production in long-term (Kumar et al., 2015; Singh et al., 2017). It is also necessary to provide the research projects to agriculture scientists and researchers, which will be useful for them to discover more technologies, high yielding verities of seed and heat tolerance crops. Consequently, it will be effective to mitigate the adverse effect of climate change in agriculture production activities. Shorter cycle crop varieties 
of seeds, mixed and intercropping, droughttolerant crops, change in farm management practices may be an adaptation to mitigate the adverse effect of climate change in crop farming (Birthal et al., 2014; Herath and Thirumarpan, 2017). Change in plating time and sowing methods may be another adaptation technique to reduce negative consequences on climate change in farming.

Moreover, there are many other reasons which are vulnerable to agriculture activities in India and other larger agrarian economies. These reasons are noticed as: low size of land holding and lack of mechanization, farmers are using traditional techniques and low quality of seeds in farming, lack of irrigation facilities, high dependency of on rain, low economic capacity of farmers, lack of water management systems, low government spending on agriculture research and development, ineffective mechanisms of the government towards agricultural and rural development, high dependency of population on agriculture sector, use of agricultural land for non-agriculture activities, decreasing arable land due to urbanization and industrialization, farmers not having appropriate ideas and knowledge to mitigate the negative consequences of climate change, low financial support from banking and financial organizations for farmers, use of extensive fertilizer in cultivation, decreasing soil quality and fertility, and others (Chen et al., 2004; Zilberman et al., 2004; Eid et al., 2006; Horowitz, 2009; Cabas et al., 2009; Falco et al., 2011; Kumar and Sharma, 2014; Amin et al., 2015; Kumar et al., 2017; Panda et al., 2019; Imran et al., 2019). Therefore, policy makers are required to focus on aforesaid activities to sustain food-grain production and food security in near future. Greenhouse gases (GHGs) emission (i.e. $\mathrm{CO}, \mathrm{CO}_{2}, \mathrm{~N}_{2} \mathrm{O}, \mathrm{CH}_{4}, \mathrm{NH}_{4}$ ) are increasing due to agriculture and industrial activities, and high urbanization, industrialization and population growth (Mendelsohn et al., 1994; Quiggin and Horowitz, 2003; Zilberman et al., 2004; Imran et al., 2019). Thus, extensive GHGs emission produces global warming and make high changes in climatic factors (Toby et al., 1992; Quiggin and Horowitz, 2003; Zilberman et al., 2004; Mendelsohn et al., 1994). Hence, if climate change happens, then impact of aforesaid activities on agriculture will be higher in future. So, developing economies need to centralize their policies to reduce the climate change impact on farming sector to sustain socio-economic activities and food security.

This present study compiles state-wise in panel of climatic and non-climatic variables during 1977-2014 and produce the projected food-grain production and yield in future. These Indian states have a high diversity in socio-economic condition of farmers, geographical conditions, agriculture policies, public spending on agriculture and rural development. Whilst, this study could not capture the impact of inter-states disparity of aforementioned factors on foodgrain production and yield. Existing researcher, can therefore consider aforementioned factors in further study. In addition, the present study also could not provide the projected food-grain production and yield for individual state. Thus, existing researchers may estimate projected food-grain production and yield at state level.

\section{ACKNOWLEDGEMENT}

The prime author of this study is thankful to the DIT University Dehradun for providing all research facilities to complete this research.

\section{Disclaimer}

The present study is purposed by Ajay K. Singh and segregation and compilation of data is finished by Bhim Jyoti. Formulation of empirical models and their examination are done by Ajay K. Singh. Finalization of empirical results and their interpretation is discussed by both the authors. Final draft of this article is completed by both the authors. Both authors have full agreement to publish it and do not have any interest of conflict. 


\section{REFERENCES}

Abeysingha N.S., Singh M., Islam A. and Seghal V.K. (2016). Climate change impacts on irrigated rice and wheat production in Gomti River basin of India: A case study. SpringerPlus. 5(125):120. https://doi.org/10.1186/s40064-016-2905-y

Adams R.M., Hurd B.H., Lenhart S. and Leary N. (1998). Effect of global climate change on agriculture: An interpretative review. Climate Research. 11(1):19-30. https://doi.org/10.3354/ cr011019

Akintunde O.K., Okoruwa V.O. and Adeoti A.I. (2013). The effect of agroclimatic factors on cash crops production in Nigeria. Journal of Central European Agriculture. 14(3):905- 927. https:// doi.org/10.5513/jcea01/14.3.1284

Alam Md.Q. (2013). Climate change, agriculture productivity and economic growth in India: The bound test analysis. International Journal of Applied Research and Studies. 2(11):1-14.

Amin Md. R., Zhang J. and Yang M. (2015). Effects of climate change on the yield and cropping area of major food crops: A case of Bangladesh. Sustainability. 7(1):898-915. https://doi. org/10.3390/su7010898

Attri S.D. and Rathore L.S. (2003). Simulation of impact of projected climate change on wheat in India. International Journal of Climatology. 23(1):693-705. https://doi.org/10.1002/joc.896

Auffhammer, M., Ramanathan, V. and Vincent, J.R. (2011). Climate change, the monsoon, and rice yield in India. Climate Change. 111(1):411-424. https://doi.org/10.1007/s10584-011-0208-4

Basak J.K., Ali M.A., Islam N.Md. and Rashid Md.A(2010). Assessment of the effect of climate change on boro rice production in Bangladesh using DSSAT model. Journal of Civil Engineering. 38(2):95-108.

Birthal P.S., Khan Md.T., Negi D.S. and Agarwal S. (2014). Impact of climate change on yields of major food crops in India: Implications for food security. Agriculture Economics Research Review. 27(2):145-155. https://doi.org/10.5958/0974-0279.2014.00019.6

Cabas J., Weersink A. and Olale E. (2009). Crop yield response to economic, site and climate variables. Climatic Change. 101(1):599-616. https://doi.org/10.1007/s10584-009-9754-4

Chen C.C., McCarl B.A. and Schimmelpfennig D.E. (2004). Yield variability as influenced by climate: A statistical investigation. Climate Change. 66(1):239-261. https://doi.org/10.1023/ b:clim.0000043159.33816.e5

Darwin R. (1999). A farmer's view of the Ricardian approach to measuring agricultural effects of climate change. Climate Change. 41(1):371-411.

Eid H., El-Marsafawy S. and Ouda S. (2006). Assessing the economic impacts of climate change on agriculture in Egypt: a Ricardian approach. CEEPA Discussion Paper No. 16, Centre for Environmental Economics and Policy in Africa, University of Pretoria. https://doi. org/10.1596/1813-9450-4293

Falco D.S., Yesuf M., Kohlin G. and Ringler C. (2011). Estimating the impact of climate change on agriculture in low-income countries: Household level evidence from the Nile Basin, Ethiopia. Environmental Resource Economics. 52(1):457-478. https://doi.org/10.1007/s10640-0119538-y 
Guntukula R. (2019). Assessing the impact of climate change on Indian agriculture: Evidence from major crop yield. Journal of Public Affairs. 20(1):1-7. https://doi.org/10.1002/pa.2040

Herath, H. M. L. and Thirumarpan K. (2017). Climate change induced adaptation strategies by paddy farmers: Special emphasis on social economic insights. Journal of Agricultural Sciences. 12(2):124 -137. https://doi.org/10.4038/jas.v12i2.8230

Horowitz J.K. (2009). The income-temperature relationship in a cross-section of countries and implications for predicting the effects of global warming. Environmental Resource Economics. 44(1):475-493. https://doi.org/10.1007/s10640-009-9296-2

Imran A., Hussain Z., Shabbir M., Waseem L. and Naqvi A.A. (2019). Climate change and its impact on the agriculture sector in selected South Asian countries. Int. J. Econ. Environ. Geol. 10(4):97101. https://doi.org/10.46660/ijeeg.vol10.iss4.2019.360

Jha B. and Tripathi A. (2011). Isn't climate change affecting wheat productivity in India? Indian Journal of Agricultural Economics. 66(3):353-364.

Jyoti B. and Singh A.K. (2020). Projected sugarcane yield in different climate change scenarios in Indian states: A state-wise panel data exploration. International Journal of Food and Agricultural Economics, 8(4):343-365.

Kumar A. and Sharma P. (2014). Climate change and sugarcane productivity in India: An econometric analysis. Journal of Social and Development Sciences. 5(2):111-122. https://doi.org/10.22610/ jsds.v5i2.811

Kumar A., Ahmad M.M. and Sharma P. (2017). Influence of climatic and non-climatic factors on sustainable food security in India: A statistical investigation. International Journal of Sustainable Agricultural Management and Informatics. 3(1):1- 30. https://doi.org/10.1504/ ijsami.2017.10003789

Kumar A., Sharma P. and Ambrammal S.K. (2014). Climatic effects on food grain productivity in India: A crop wise analysis. Journal of Studies in Dynamics and Change. 1(1):38- 48.

Kumar A., Sharma P. and Joshi S. (2015). Effect of climatic factors on agricultural productivity in India: A state-wise panel data analysis. International journal of Basic and Life Sciences. 3(1):48-67.

Kumar A., Sharma P. and Joshi S. (2016). Assessing the impacts of climatic change on land productivity in Indian crop agriculture: An evidence from panel data analysis. Journal of Agriculture Science and Technology. 18(1):1-13.

Mendelsohn R., Nordhaus W. and Shaw D. (1994). The impact of global warming on agriculture: A Ricardian analysis. The American Economic Review. 84(4):753-771. https://doi. org/10.4324/9781351161602-15

Mendelsohn R., Dinar A. and William L. (2006). The distributional impact of climate change on rich and poor countries. Environment and Development Economics. 11(1):159-178. https://doi. org/10.1017/s1355770x05002755

Mondal P., Jain M., DeFries R.S., Galford G.L. and Small C. (2015). Sensitivity of crop cover to climate variability: Insights from two Indian agro-ecoregions. Journal of Environment Management. 148(1):21-30. https://doi.org/10.1016/j.jenvman.2014.02.026 
Mondal P., Jain M., Robertson A., Galford G.L., Small C. and DeFries R.S. (2014). Winter crop sensitivity to inter-annual climate variability in central India. Climate Change. 126(1):61-76. https://doi.org/10.1007/s10584-014-1216-y

Olanrewaju, R.M., Tilakasiri, S.L. and Oso, C. (2017). Climate change and rice production: A case study in Ekiti State, Nigeria. The Journal of Agricultural Sciences. 12(2):95-107. https://doi. org/10.4038/jas.v12i2.8228

Panda A., Sahu N., Behera S., Sayama T., Sahu L., Avtar R., Singh R.B. and Yamada M. (2019). Impact of climate variability on crop yield in Kalahandi, Bolangir, and Koraput districts of Odisha, India. Climate. 7(126):1-12. https://doi.org/10.3390/cli7110126

Panda R.K., Alam J. and Nandgude S. (2012). Effect of climate variability on maize yield and evaluation of coping strategies using the crop growth model. The International Journal of Climate Change: Impacts and Responses. 3(2):71-94. https://doi.org/10.18848/1835-7156/cgp/ $\mathrm{v} 03 \mathrm{i} 02 / 37102$

Quiggin J. and Horowitz J. (2003). Costs of adjustment to climate change. The Australian Journal of Agricultural and Resource Economics. 47(4):429-446. https://doi.org/10.1111/j.14678489.2003.00222.x

Reddy, G.P. (2006). Impact of water management on production of rice in Balipatna command area of Orissa, India. Journal of Agriculture Science-Sri Lanka, 1(2):15-20. https://doi.org/10.4038/ jas.v1i2.8093

Singh A.K. and Issac J. (2018). Impact of climatic and non-climatic factors on sustainable livelihood security in Gujarat state of India: A statistical exploration. Agriculture and Food Sciences Research. 5(1):30-46. https://doi.org/10.20448/journal.512.2018.51.30.46

Singh A.K. and Jyoti B. (2019). Measuring the climate variability impact on cash crops farming in India: An empirical investigation. Agriculture and Food Sciences Research. 6(2):155-165. https://doi.org/10.20448/journal.512.2019.62.155.165

Singh A.K. and Sharma P. (2018). Measuring the productivity of food-grain crops in different climate change scenarios in India: An evidence from time series investigation. Climate Change. 4(16):661-673.

Singh A.K. and Singh B.J. (2020). Assessing the infectious diseases of students in different weather seasons in DIT University Dehradun, Uttarakhand (India). Asian Journal of Multidimensional Research. 9(3):34-48. https://doi.org/10.5958/2278-4853.2020.00055.5

Singh A.K., Narayanan K.G.S, and Sharma P. (2017). Effect of climatic factors on cash crop farming in India: An application of Cobb-Douglas production function model. International Journal of Agricultural Resources, Governance and Ecology. 13(2):175- 210. https://doi.org/10.1504/ ijarge.2017.10007474

Singh A.K., Sharma P. and Singh D.K. (2016). Measuring the influence of weather variables on productivity of food-grain crops in India: An application of Just \& Pope's production technique. ABBS Management Business and Entrepreneurship Review. 7(2):29-46. https://doi. org/10.23874/amber/2016/v7/i2/121780

Singh A.K. and Narayanan K.G.S (2018). Climate change, food-grain farming and food security in India. LAP LAMBERT Academic Publishing, Mauritius. 
Smit B. and Skinner M.W. (2002). Adaptation options in agriculture to climate change: a typology. Mitigation and Adaptation Strategies for Global Change. 7(1):85-114. https://doi. org/10.1023/a:1015862228270

Toby J., Reilly J. and Kane S. (1992). Economic implications of global climate change for world agriculture. Journal of Agricultural and Resource Economics, 17(1):195-204.

Yadav M.K., Singh R.S., Singh K.K., Mall R.K., Patel C.B., Yadav S.K. and Singh M.K. (2015). Assessment of climate change impact on productivity of different cereal crops in Varanasi, India. Journal of Agrometeorology. 17(2):179-184.

Zhai Z., Lin T. and Byambadorj E. (2009). A general equilibrium analysis of the impact of climate change on agriculture in the People's Republic of China. Asian Development Review. 26(1):206225 .

Zilberman D., Liu X., Roland-Holst D. and Sunding D. (2004). The economics of climate change in agriculture. Mitigation and Adaptation Strategies for Global Change. 9(1):365-382. https://doi. org/10.1023/b:miti.0000038844.72226.13 